\title{
Tradition as Innovation: Dialect Revalorization and Maximal Orthographic Distinction in Rural Norwegian Writing
}

Thea R. Strand

Loyola University Chicago, tstrand@luc.edu

Follow this and additional works at: https://ecommons.luc.edu/anthropology_facpubs

Part of the Anthropology Commons

\section{Recommended Citation}

Strand, Thea R.. Tradition as Innovation: Dialect Revalorization and Maximal Orthographic Distinction in Rural Norwegian Writing. Multilingua, 38, 1: 51-68, 2018. Retrieved from Loyola eCommons, Anthropology: Faculty Publications and Other Works, http://dx.doi.org/10.1515/multi-2018-0006

This Article is brought to you for free and open access by the Faculty Publications and Other Works by Department at Loyola eCommons. It has been accepted for inclusion in Anthropology: Faculty Publications and Other Works by an authorized administrator of Loyola eCommons. For more information, please contact ecommons@luc.edu. cc) (i) $\Theta$

This work is licensed under a Creative Commons Attribution-Noncommercial-No Derivative Works 3.0 License. (C) De Gruyter 2018 


\title{
Thea R. Strand*
}

\section{Tradition as innovation: Dialect revaloriza- tion and maximal orthographic distinction in rural Norwegian writing}

https://doi.org/10.1515/multi-2018-0006

\begin{abstract}
In rural Valdres, Norway, the traditional regional dialect, called Valdresmål, has become an important resource for popular style and local development projects. Stigmatized through much of the twentieth century for its association with poor, rural, "backward" farmers and culture, Valdresmål has been thoroughly revalorized, with particularly high status among local youth and those involved in business and tourism. While today's parents and grandparents attest to historical pressures to adopt normative urban linguistic forms, many in Valdres now proclaim dialect pride and have re-embraced spoken Valdresmål in various forms of public, interdialectal communication. In addition, Valdres natives also make abundant and creative use of dialect on social media, the primary locus for written Valdresmål and for emergent orthographic norms representing local speech, including strategies of maximal sociolinguistic distinction. This innovative use of written Valdresmål has been taken up by local businesses as a marketing strategy in recent years, as well, further normalizing and legitimating nonstandard forms. In the ongoing revalorization of traditional Valdresmål, it is also, inevitably, transformed-linguistically, socially, and ideologically-as it enters and circulates within new and innovative cultural domains: while widespread written Valdresmål challenges the normal sociolinguistic order, in such a process the dialect is also refunctionalized and, perhaps, increasingly standardized.
\end{abstract}

Keywords: dialect, Norwegian, nonstandard orthography, digital communication

\section{Introduction}

In rural Valdres, Norway, the traditional regional dialect, called Valdresmål or, more colloquially, Vallers, has become an important resource for youthful and

*Corresponding author: Thea R. Strand, Department of Anthropology, Loyola University Chicago, 1032 W. Sheridan Rd., Chicago, IL 60660, USA, E-mail: tstrand@LUC.edu 
popular style. For most of the twentieth century, Valdresmål, along with countless other rural Norwegian dialects (dialekter or målføre ${ }^{1}$ ), was stigmatized for its association with poor, "backward" farmers and culture. While spoken Valdresmål continued to be used among the majority of the resident population in local contexts throughout the twentieth century, as has been true for local and regional dialects in much of Norway (cf. Jahr and Janicki 1995; Nesse 2015), gradual grammatical standardization, including the loss of the dative case and noun- and verb-class distinctions, among other things, was clearly present in Valdres at least from the post-war period (Beito 1959; Aars 1963; Wangensteen 1971). However, widespread perception of, and concern about, dialect shift and loss in Valdres does not seem to have emerged until the late twentieth century, when young Valdres residents led a significant dialect shift toward more normative, urban spoken forms, both grammatical and lexical (Kvåle 1999).

In the twenty-first century, however, as the rural district of Valdres has undergone an economic shift away from its historical agricultural base and become a premiere domestic tourism destination, Valdresmål is perhaps cooler than ever, with particularly high status among local youth (Strand 2012b). While their parents and grandparents attest to historical pressures to adopt more normative urban forms, as has been the dominant pattern throughout Europe (see Auer et al. 2005), many young people in Valdres now proclaim dialect pride and have re-embraced Valdresmål not only in familiar local contexts but also in various forms of public, interdialectal communication (Strand 2012a, 2015). In addition to employing dialect in spoken interaction, Valdres natives make abundant and creative use of dialect in digital communication, including social media, which has become the primary locus for written Valdresmål and for emergent orthographic norms for representing local speech. Over the last several years, the innovative use of written Valdresmål has also been taken up as a marketing strategy by local businesses involved in the booming local tourism industry, further normalizing and legitimating nonstandard forms.

In this article, I argue that, in addition to contributing to the revalorization of Valdresmål and the public demonstration of linguistic and cultural pride, with some potential for real profit (Duchêne and Heller 2012), the recent profusion of both everyday and commercial uses of written Valdresmål employs nonstandard orthography that is maximally distinctive. As Valdresmål speakers consistently incorporate more non-normative forms in their written communication, and as they use spellings that diverge from standard ones more than

1 Dialekt is the label most commonly attached to local and regional language forms in Norway. A more academic synonym is målføre, widely recognized but rarely used in everyday contexts. I therefore use the cognate dialect, though code is perhaps just as relevant. 
strictly necessary to represent what is distinctive in local speech, they reinforce long-standing, historically politicized divides between rural and urban places, people, and language in Norway. Ultimately, in the present return to and revalorization of traditional Valdresmål, we can observe that it is, inevitably, transformed-linguistically, socially, and ideologically-as it enters and circulates within new and innovative cultural domains. This article aims to examine these transformations and their effects.

Below, I begin with a brief explanation of the national and local contexts, followed by a consideration of some of the orthographic and ideological processes involved in this example of dialect revalorization and refunctionalization. I then discuss several representative examples of written Valdresmål in digital communication and marketing, concluding with reflections on the implications of utilizing a traditionally spoken regional dialect in such innovative ways.

\section{National and local background}

For well over a century, Norwegian has had two distinct written norms. Called Bokmål (lit. 'book language') and Nynorsk (lit. 'new Norwegian') in the contemporary period, these two official, national written varieties (målformer) are legally equivalent. The Bokmål written norm, as it exists today, is a relic of Danish rule, when written Danish replaced Old Norwegian as the administrative language of the state and the post-Reformation church. Today, many decades after a protracted and highly politicized language-planning struggle largely subsided in the 1960s (see Haugen 1966; Bucken-Knapp 2003; and Jahr 2014; for details in English), Dano-Norwegian Bokmål (previously called Riksmål 'language of the kingdom') is the dominant written form of Norwegian. Through historicallygrounded linguistic and semiotic ideologies (Woolard and Schieffelin 1994; Irvine and Gal 2000), it continues to be associated with modernity, cosmopolitanism, and with urban Oslo, Norway's largest city, located about 180 kilometers (110 miles, roughly a three-hour drive) from central Valdres.

The Nynorsk written norm, on the other hand, was originally a postindependence project begun by Norwegian linguists around 1840. As a selfconsciously nationalist project, Nynorsk (previously called Landsmål 'language of the country,2) sought to include Norwegian linguistic forms and features that

2 Land can be glossed as both 'countryside' and 'nation,' similar to country in English, and it has been suggested that this ambivalence in the meaning of Landsmål ('rural language' or 'national language') was intentional (Haugen 1966: 34). 
were furthest from, or least influenced by, Danish or Swedish. The Nynorsk written norm thus emphasizes grammatical and lexical forms that were widespread in the "conservative" spoken dialects of Western and Midland Norway in the mid- to late-nineteenth century, believed to be closest to Old Norwegian (Haugen 1966). Since its initial development, the constructed Nynorsk norm has been accepted by many because of its perception as nationally Norwegian, though today perhaps only about $15 \%$ of the population regularly writes in Nynorsk, with users predictably concentrated in Western and rural Midland regions. Thus, despite their mostly overlapping linguistic structures, Bokmål and Nynorsk have been ideologically conceptualized as distinct codes, with neither of these standardized written forms understood to be an entirely neutral choice in writing.

In contemporary Norway, Bokmål and Nynorsk remain co-official, with all pupils required to gain literacy skills in both, indexing broad political support for Norwegian sociolinguistic variation, which also extends to spoken dialects (cf. Røyneland 2009). In both popular and scholarly discourse about language variation, it is often alleged that "Norwegians use local dialects more often and to a much larger degree than other European nations" (Jahr and Janicki 1995: 30), including in many formal and institutional contexts, such as schools and universities, parliament, national broadcasting, and theatrical productions (Nesse 2015). However, there has historically been a clear ideological distinction between spoken language, where dialect use is welcome and even expected (Sandøy 2009; Mæhlum 2009; Nesse 2015), and written language, which demands the use of either Bokmål or Nynorsk, though both of the written norms do permit some internal variation, so that writers have some freedom to use normative forms closest to their own spoken dialect if available and desired. $^{3}$

Both of the written norms are taught and used in my ethnographic fieldsite, the Valdres valley in east-central Norway, and, as noted above, many Valdres residents also continue to speak Valdresmål. Valdres remains a mostly rural district, with spectacular mountains on three sides and a large number of cultural and archaeological attractions in its lower valleys, as well as a long tradition of small-scale, transhumant dairy and sheep farming. I have conducted ethnographic and sociolinguistic fieldwork in central Valdres since 2004,

3 For instance, Bokmål allows writers to use three grammatical gender categories, as in Old Norwegian and many Midland and Western dialects, or just two gender categories, as in Danish and many Eastern and Southern Norwegian dialects. While Nynorsk uses three gender categories consistently, it allows two different forms for the infinitive verb marker, representing regionally variable phonology. 
including 15 months spent living, working as a farmhand, and doing research there in 2007-08 to gather data for my dissertation. Since then, I have returned to Valdres for at least a month nearly every summer, keeping current in local affairs and collecting examples of written, public dialect use when opportunities arise. In addition, when I am not physically present in Valdres, I maintain contact and stay up to date via online news and social media, and the representative examples of written Valdresmål analyzed below were collected through participation in and observation of digital social media platforms used by Valdres residents and natives over the last two years (2017-2018).

Today, Valdres is home to about 18,000 permanent residents and roughly the same number of vacation cabins (Jullumstrø 2014), which are owned or used primarily by urban Norwegians. This is indicative of a successful economic turn from family farming to tourism in recent years, in which a cooperative local administrative organization has spearheaded the effort to develop Valdres as a leading recreational and cultural tourism destination in Norway. While Valdres has had a tourism industry since the turn of the twentieth century, when a rail line from Oslo to central Valdres was completed in 1906, in the twenty-first century the rural valley has been officially designated the Valdres Natur- og Kulturpark 'Valdres Nature and Culture Park' (or VNK), with buy-in from local government and business leaders. This development has been especially focused on outdoor recreational activities and cultural traditions involving food and folk music; however, one of the 13 goals specified in the original VNK administrative charter from 2007 is to "stimulate the use of the Valdres dialect," indexing popular recognition of the potential value of Valdresmål as a profitable source of distinction in a crowded tourism marketplace. A turn toward emphasizing linguistic difference and distinctiveness for social and/or economic gain is, of course, not unique to Valdres, as Irvine (2001) and Duchêne and Heller (2012), among others, have clearly demonstrated. Heller, for instance, has carefully documented a turn from ethnonationalist language politics in Fracophone Canada to a view of language as (part of) successful cultural tourism projects, in which "language plays an important role in the authentication process" (2011: 27). Yet, the emphasis on linguistic distinctiveness across so many modes and sites of communication in Valdres, involving so many individual speakers and writers in mostly unplanned communicative events, does seem to represent a new and relatively unexplored example of linguistic differentiation and commodification.

It is thus within the context of a somewhat unusual degree of written and spoken heteroglossia (Bakhtin 1981) throughout Norway, along with Valdres' political-economic transition from agriculture to tourism as a primary industry, that I aim to analyze recent developments in written dialect use and their entailments. 


\section{Nonstandard orthography and sociolinguistic distance}

As we have seen in language revitalization projects in Europe and beyond over the last several decades, developing a written norm and working toward widespread acceptance for the particular set of linguistic forms represented in writing can be one of the most difficult and contentious parts of the process (see, e.g., Fishman 1991; Crystal 2000; Schieffelin and Doucet 1992; Jaffe 1999; Wroblewski 2012). As Jaffe writes, “in that control of writing standards both reflects and confers cultural and political power, it is no surprise that orthography has been the center of numerous cultural debates all over the world” (Jaffe 1996: 819). Even with overwhelming community support for language revitalization projects, disagreements over which variants to include or exclude in a new written norm have the potential to derail language planners and erode popular support. However, this case of dialect revalorization does not fit the familiar pattern, as there is no centralized planning of a new written norm and, arguably, less overt authority inherent in the new orthographic conventions that are being established. Contemporary Valdresmål writers have not deliberately set out to craft a new norm, though that may ultimately be one outcome of the processes observed in this article. Instead, Valdresmål writers, in both interpersonal and commercial contexts, are using non-normative orthography to represent non-normative speech in ways that point to "authenticity" and distinctive style or "flavor" (Jaffe 2000: 498). Nonstandard writing here indexes a particularized, if stereotypical, authentic speaker through persistent links between rural places, personae, and linguistic features, and, as elsewhere, points to an "authenticating heartland" (Duchêne and Heller 2012: 11) in the rural, mountainous district of Valdres, imagined as representative of a symbolically valuable, historically rural national identity (Eriksen 1993; Ween and Abram 2012).

Despite the high symbolic value of rural spaces in Norway, many native Valdres residents do not feel that the realities of rural life and practice are understood or valued by urban outsiders. Additionally, the national dominance of Bokmål and the regional dominance of "Urban Eastern Norwegian" speech (cf. Røyneland 2009), which Valdres residents generally call Bokmål or bymål 'city language,' at times appear to contradict nationally normative ideologies valuing dialect diversity and rural dialects in particular (Strand 2012b). There is thus an important political dimension to the use of nonstandard orthography in written Valdresmål, even in linguistically liberal Norway. On this issue, Jaffe has argued that 
the powerful symbolic coupling of standard orthographies with linguistic and social authority and legitimacy limits the subversive potential of nonstandard orthography. That is, every use of a non-standard form silently invokes the prescriptive power of the standard language myth which by definition discredits both the voices represented by nonstandard spellings and the spellings themselves (Jaffe 2000: 511).

While I agree that this is generally the case, I contend that there is presently little risk to the writing subject using nonstandard orthography to represent traditionally spoken Valdresmål in certain domains. As Jaffe's work implies, written Valdresmål does necessarily index normative orthographic conventions and a general expectation of standard orthography, but the sociolinguistic distinction that is being attended to in digital, commercial, and heritage-tourism contexts is one that offers profits, whether social or economic, to Valdresmål writers.

The support and involvement of local economic and political leaders in the written Valdresmål trend is critical here, producing an alternative sociolinguistic marketplace (Woolard 1985), in which claiming linguistic and cultural distinctiveness by orthographic means also effectively establishes desirable distance between rural and urban people and language. This is very much in line with Sebba's observation that abstand is a common goal in vernacular orthographies (Sebba 2007: 131). Marking distance orthographically also further reifies dominant ideologies that presume distance and a more or less dichotomous separation between rural and urban Norway, despite the obvious realities of contemporary interconnectedness and mobility. However, the indexical effect here is not to suggest any privilege for the urban over the rural (or vice versa, necessarily), merely a (largely implicit) desire to maintain these as socially and linguistically distinct categories, given their historically unequal power relations.

Significantly, the present example of innovative sociolinguistic practice using nonstandard orthography also occurs in a historical moment that involves dramatic increases in the use of writing for frequent, casual, and everyday social interaction. This novel context has allowed for the negotiation of acceptable and preferred written forms to be diffuse and emergent (Androutsopoulos 2011; Eisentstein 2015). Anyone and everyone may contribute through actions as mundane as sending a text message (SMS) or posting a comment on social media. With so many language users and media involved simultaneously in the development of a newly written form of Valdresmål, we might expect tremendous diversity and a lengthy process of negotiation over the most important, phonetically accurate, or efficient orthographic representations for this and other newly written language forms. Though still understudied and 
undertheorized, emerging research examining nonstandard orthography in digital communication in fact suggests that agreement on nonstandard spellings happens quite quickly. For example, in a quantitative corpus-based analysis of nonstandard orthographic forms associated with African American English on Twitter, Jones (2015) finds clear, geographically limited trends for distinctive orthographic variants, indicating broad agreement within newly identified regional dialect areas of AAE. Importantly, as Jones points out, "these are not misspellings, nonce words, or one-off coinages" (Jones 2015: 406); rather, as in the case of written Valdresmål, message writers appear to have very good control of both standard and nonstandard orthographic conventions, and there is evident agreement within the author population.

Additionally, in both of these cases, the self-representation of nonstandard language in digital writing approaches what has sometimes been called "eyedialect" in critical sociolinguistic and anthropological analyses of transcribed speech, in which the speech of socially marginalized speakers is made to look far more different from supposedly standard speech than it actually is (Preston 1982, 1985; Bucholtz 2007; Jaffe 2008). However, the example at hand is not one of external Othering, out of the control of the speakers whose language is represented in written form; urban outsiders are not using nonstandard orthography to represent Valdresmål speakers as unintelligent or backward. Instead, this trend in writing Valdresmål is part of a larger set of innovative and popular cultural and stylistic practices among Valdres residents that (re-)valorize the local, the rural, the traditional and de-privilege, or at least destabilize, a historical preference for all that counts as urban, modern, and cosmopolitan, sometimes in pursuit of heritage tourism profit.

In order to illustrate some of these dynamics, I turn now to specific examples of nonstandard orthography in written Valdresmål, first addressing digital communication, then uptake in the domain of advertising.

\section{Writing Valdresmål}

In the contemporary use of written Valdresmål, digital technology and the associated considerable shift toward more frequent, casual writing has provided an important and unprecedented site for the development of innovative orthographic practice. Youth-led trends in nonstandard orthography in digital writing in Valdres began, as elsewhere, early in the internet era. However, the widespread and pervasive use of traditional dialect forms in writing that is easily observable today was just nascent in 2007-08, when I lived in Valdres for 15 
months conducting ethnographic and linguistic research. Witnessing the rapid increase in nonstandard orthographic representations of Valdresmål firsthand, it appears to me to be tied in part to changing mobile phone technology. Particularly regarding what is important to mark as distinctly nonstandard, systematic agreement seems to coincide with the time period when full-keyboard mobile phones became standard in the area, around 2011 or 2012.

Text messaging (SMS) was popular in Norway and Valdres by the early 2000s, but early SMS-writers everywhere were constrained by key pads with only numbered buttons that had to be pressed up to four times for a particular letter, leading most users to abbreviate as much as possible. Before smartphones, however, the slow and tedious typing systems on basic cell phones were made more efficient with the introduction of so-called T9 texting that featured "predictive" technology, allowing for fewer key taps as the phone suggested the message writer's probable intent based on a pre-loaded, standard dictionary. Thus, in the early 2000s, many SMS-writers used mostly standard orthography, as it was much faster to type a message using the T9 system. A unique dilemma for Norwegian mobile phone users was (and still is) the forced choice between Bokmål and Nynorsk for both their phone's interface and dictionary, and Valdres residents used one or the other based on personal (and sometimes political) preference. For one young Valdresmål speaker I interviewed in 2008, the T9 system meant using "mostly Nynorsk sprinkled with dialect to the extent that the predictive dictionary can handle it."

"But," she added, "I've saved a few dialect words [to the phone's dictionary] that I feel like I have to have.” Among these, she told me, was the adjective gøtt 'good' (neut.), spelled godt in both Bokmål and Nynorsk.

Gøtt turns out to be an excellent example of a dialect form that is consistently re-spelled by Valdremål writers in the late 2010s. It is also one realization of a key phonological distinction between Valdresmål and surrounding dialects that is at the level of metalinguistic awareness in Valdres. When I have asked people, without much forewarning, to name some of the most salient dialect features, the sound $/ \varnothing /$ is frequently mentioned as an important part of what distinguishes Valdresmål from other varieties of Norwegian. And, indeed, there is a systematic difference between Valdresmål and Urban Eastern Norwegian in certain linguistic environments, where Valdresmål uses /ø/ and urban speech uses /o/. Gøtt is a particularly high-frequency lexeme that illustrates this difference, and choosing a markedly local and nonstandard orthographic form for very high-frequency words is a prevailing pattern today.

Another significant nonstandard orthographic pattern exemplified in the spelling of gøtt is that more is changed from the prescribed spelling than strictly necessary to reflect the local pronunciation: in speech, the vowel sound is 
distinctive, but the consonants are the same in Valdresmål and other dialects. Nevertheless, the standard spelling of the word-final consonant, $-d t$, is changed to - $t$, despite the fact that orthographic - $d t$ only ever corresponds to the sound/ $\mathrm{t} /$ in contemporary Norwegian speech. The choice to use -tt makes the written form gøtt look more distinct from godt, and this is part of a broader, emergent pattern showing a preference for more marked orthographic difference in written dialect, again especially for high-frequency forms.

Among Valdresmål's distinctive, high-frequency forms most commonly represented in nonstandard orthography are pronouns, prepositions, and other lexemes for which are not good matches in either Bokmål or Nynorsk dictionaries, as for the examples shown in Table 1.

Table 1: Examples of high-frequency Valdresmål forms commonly represented with nonstandard orthography.

\begin{tabular}{llllll}
\hline English & Valdresmål (central) & Written Vm & UEN & Bokmål & Nynorsk \\
\hline $\mathrm{I}$ & $/ \mathrm{e}: /$ & $\mathrm{e}$ & $/ \mathrm{jai} /$ & $\mathrm{jeg}$ & $\mathrm{eg}$ \\
we & $/ \mathrm{m} \varnothing /$ & $\mathrm{m} \varnothing$ & $/ \mathrm{vi} /$ & $\mathrm{vi}$ & $\mathrm{vi}, \mathrm{me}$ \\
you-pl. & $/ \mathrm{d} \varnothing /$ & $\mathrm{d} \emptyset$ & $/ \mathrm{dere} /$ & $\mathrm{dere}$ & $\mathrm{de}$ \\
of, from & $/ \mathrm{tc} /$ & tå & $/ \mathrm{av} /$ & $\mathrm{av}$ & $\mathrm{av}$ \\
\hline
\end{tabular}

The set of written Valdresmål forms in Table 1 (and some others) have been widely used in digital writing since instant messaging and text messaging first became popular modes of communication, and there has been virtually no disagreement about spelling among those I have seen writing in Valdresmål.

On the other hand, and more recently, the popular trend of maximally distinguishing Valdresmål forms from standard ones in writing, as we saw for gøtt, has led quite quickly to innovative spellings in written communication by dialect speakers for both locally distinctive forms and forms that are much more widespread but lack a one-to-one sound-to-symbol correspondence in standard spellings (e.g., 'it' and 'with' in Table 2). Here, there has been more negotiation, and it also appears to be the case that younger dialect writers are more quickly and eagerly embracing this trend. Some common examples are included in Table 2.

Over the last several years, uses of the forms listed in Tables 1 and 2, and many others, in social media posts by native Valdres residents include many nonstandard spellings in combination, sometimes producing whole written utterances, in which every word includes at least one nonstandard orthographic element, as shown in Example 1 below, a comment on a friend's Instagram post about an upcoming event. 
Table 2: Examples of maximally distinctive nonstandard orthographic representations of Valdresmål.

\begin{tabular}{|c|c|c|c|c|c|}
\hline English & Valdresmål (central) & Written Vm & UEN & Bokmål & Nynorsk \\
\hline good-neut. & /gøt/ & $\mathrm{g} ø \mathrm{tt}$ & /got/ & godt & godt \\
\hline it, that & $/ \mathrm{de} /, / \mathrm{d} æ /$ & $\mathrm{dæ}$ & /de/ & det & det \\
\hline with, too & $/ \mathrm{me} /, / \mathrm{mæ} /$ & $m æ$ & /me/ & med & med \\
\hline be-pres. & /æ/ & æ, e & /er/ & er & er \\
\hline very & /velde/ & velde & /veldi/ & veldig & veldig \\
\hline
\end{tabular}

(1) As written in Valdresmål: E æ mæ

Bokmål: $\quad$ Jeg er med

Nynorsk: $\quad$ Eg er med

English gloss: $\quad$ 'I'm [coming] with' or 'I'm in'

Here, the writer makes orthographic choices that eschew Bokmål and Nynorsk to mark each word in the utterance, and perhaps the writer herself, as nonstandard, distinctive, and local. It is a short string of text-just three words-but they are all high-frequency words (pronoun, 'be'-pres., and preposition) and exemplify the strong pattern of marking the most common dialect words in contemporary written Valdresmål. In Example 1, the first two words ("e," the first-person pronoun and "æ," present-tense 'be') are among the most widespread spoken forms in Norway that lack a good match in either written norm, so much so that they might rightfully be considered relatively normative in spoken Norwegian. But in the written, visual form, they stand out much more, calling attention to their orthographic nonstandardness while also representing familiar, comfortable sounds.

Marking common dialect forms with nonstandard spellings is also shown in Example 2, another Instagram comment, this one praising the original poster for a craft project she had shared a picture of.

(2) As written in Valdresmål: Så flinke dø æ

$\begin{array}{ll}\text { Bokmål: } & \text { Så flinke dere er } \\ \text { Nynorsk: } & \text { Så flinke de er } \\ \text { English gloss: } & \text { 'You (pl.) are so clever/talented' }\end{array}$

In Example 2, 'be'-pres. (æ) occurs again, along with another pronoun, $d \varnothing$ 'you'-pl., subj. $D ø$ 'you'-pl. in Example 2 is very different from $e$ 'I' in Example 1, however, in that it is a distinctly local variant: while $e$ is used in a great many 
Norwegian dialects, $d \emptyset$ is limited to Valdres in its geographic distribution. It was also the object of more metalinguistic reflection in interviews I conducted in 2007-08, when some young speakers said they never or only rarely used it. Instead, younger speakers preferred the traditional object form of the secondperson plural pronoun, dikkan, in both subject and object position. Dikkan and closely related variants are much more widespread in Western and Midland dialects of Norwegian than is $d \emptyset$, but here $d \emptyset$ is used in a social media post and stands out as not only nonstandard but also quite unusual, perhaps invoking an element of rural authenticity.

Example 3, a comment written by the original poster on Instagram as a compliment to friends who took part in a shared social event, includes an instance of a Valdresmål form that happens to coincide with Nynorsk, følgje 'company/companion(s),' a useful reminder that it is often unclear whether a writer intends for a particular form to be interpreted as nonstandard, distinctly Valdresmål, or not.

(3) As written in Valdresmål: Fint følgje va dæ mæ

Bokmål: $\quad$ Fint følge var det også

Nynorsk: $\quad$ Fint følgje var det óg

English gloss: 'And there was good company too'

Følgje also happens to be relatively low frequency, but the three highfrequency words that follow in Example 3 all make use of clearly nonstandard orthography. The presently common nonstandard spellings $d æ$ 'it' and mæ 'with, too' (mæ also occurs in Example 1) are particularly interesting, in that their local pronunciation in Valdres is not markedly different from most other spoken Norwegian varieties, including most urban ones. As we saw for gøtt above. the standard spellings det and med, respectively, in both Bokmål and Nynorsk, both include a consonant that is categorically not realized in speech. Det and med cannot, therefore, be considered any more phonetically representative of urban speech than rural speech. Instead the symbolic and ideological force of det and med is what is being recognized in Valdresmål writers' newfound zeal for $d æ$ and $m æ$.

Similarly, in Example 4, a birthday greeting for a family member on Facebook, velde 'very,' gla $i$ 'love'-pres., and herle 'wonderful,' are all nonstandard by virtue of omitting an orthographically standard word-final consonant.

(4) As written: $\quad$ mø $æ$ velde gla i de, og håpa du hadde ein herle dag Bokmal: $\quad$ vi er veldig glad i deg, og håper du hadde en herlig dag 
Nynorsk: me er veldig glad i deg, og håpar du hadde ein herleg dag English 'we love you very much and hope you had a wonderful day' gloss:

As is the case for det and med in Examples 1 and 3, the word-final grapheme is simply not a part of contemporary Norwegian phonology, neither in Valdresmål nor other dialects, though standard spellings in both written norms still include such word-final graphemes systematically. On the whole, an ideology of maximal differentiation that also demands some attention to phonological context (as in Eisentstein 2015) seems to prevail in the messages in Examples 1-4 and countless others across a wide range of digital writing platforms.

In the above examples and so many others, Valdresmål writers emphatically claim a distinctive, local, rural identity and style, in a political-economic context that increasingly offers some institutional support and legitimacy. Perhaps most significantly, as noted in Section 2, the nonstandard orthographic representation of Valdresmål has also recently been welcomed as a marketing strategy for businesses involved in the tourism industry, looking to distinguish themselves from the competition. For instance, a number of small businesses have popped up in the last few years that make use of Valdresmål in their very names, including Grepa Gøtt Café, an otherwise mostly typical café in one of the valley's largest shopping malls, and Agalaust, a small women's clothing store in Valdres's commercial center, the town of Fagernes (population around 1,900 in 2017). More common, though, has been the use of nonstandard orthography in visual marketing, particularly signs of all types, large and small, outdoor and indoor, as in Figures 1 and 2, from a mountain lodge/ café/convenience store and a gas station along Valdres's main highway, respectively.

I first saw a large, commercial outdoor sign representing local speech in 2012. But each summer since then, when returning to Valdres for a visit of a month or two, I have seen more innovative commercial uses of written Valdresmål: signs, store names, and other marketing making use of nonstandard orthography that is clearly intended to represent Valdresmål, and employing the same strategies as can be found in everyday digital communication, though not usually before new nonstandard orthographic forms have already circulated widely via SMS and social media. Such outwardly public commercial uses of written Valdresmål are nevertheless important to acknowledge for their potential legitimizing effect. A large and diffuse group of digital media users may ultimately be leading the nonstandard orthography trend in relatively casual domains, but local business leaders and the political organizations that support economic development, like the Valdres Nature and Culture Park administration, are important sources of authority, and their role in the larger dialect 


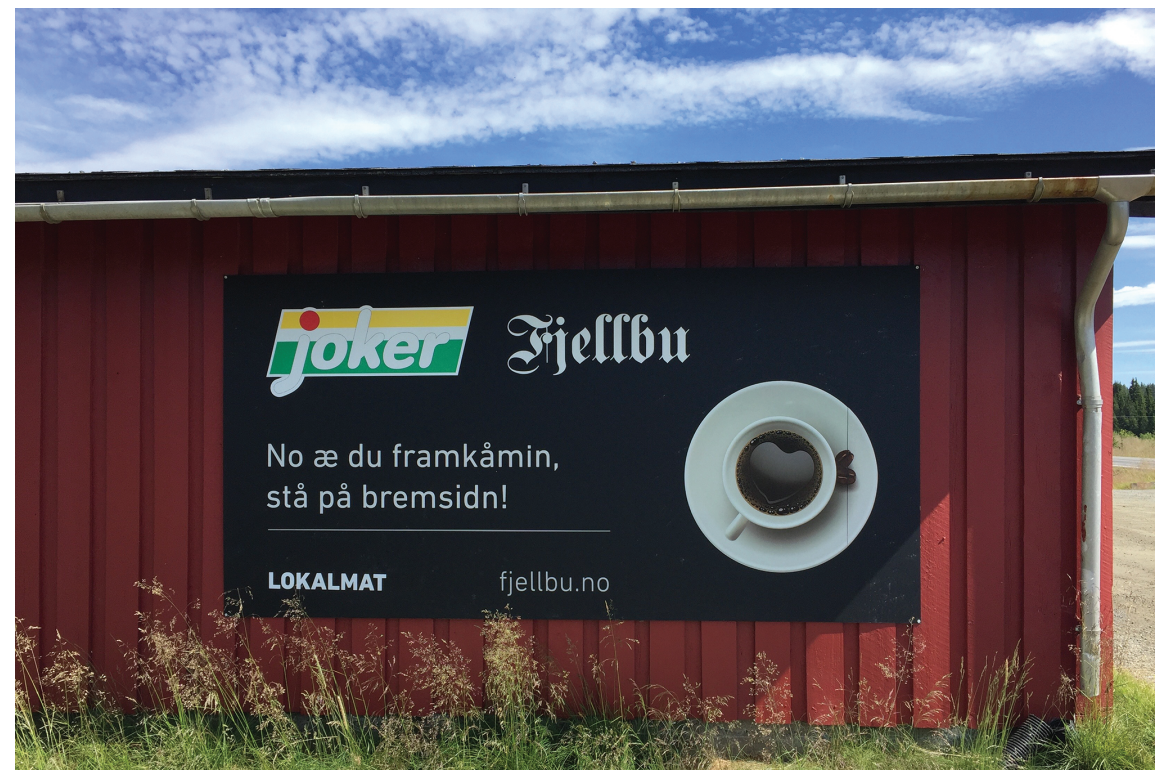

Figure 1: Roadside sign from Fjellbu mountain lodge in Valdres. As written: No æ du framkåmin, stå på bremsidn! Bokmål: Nå er du framkommet, stå på bremsene! Nynorsk: No er du framkoma, stå på bremsane! English gloss: 'Now you've arrived, hit the brakes!'

revalorization process is therefore significant. In this case, business and political leaders have not laid out any systematic plans to encourage written Valdresmål, much less particular orthographic conventions for representing the dialect, yet the overwhelming emphasis on uplifting and profiting from traditional cultural forms in the rural district has contributed to linguistic revalorization and commodification in Valdres, as well.

\section{Conclusion}

In Valdres, rural Norwegians are not just rendering a generalized informal linguistic register in writing, which seems to be a universal characteristic of digital writing in certain media (Crystal 2006; Androutsopoulos 2011); rather, the nonstandard forms and features they aim to represent in writing are particularly local, as well as culturally valuable, indexing Valdres but also much larger political-ideological discourses of a common national heritage (kulturarv 'cultural heritage/inheritance') centered on traditional rural livelihoods and landscapes, which are discursively positioned as separate from, and often at odds 


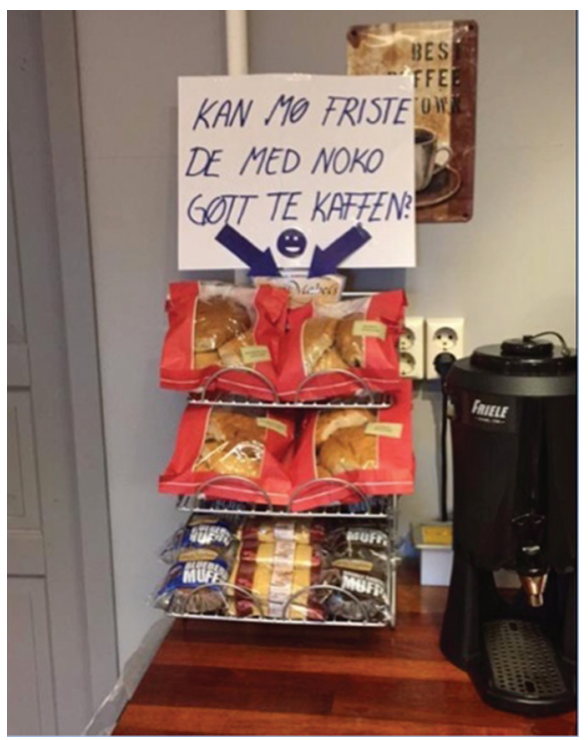

Figure 2: Handwritten sign inside a Valdres gas station. As written: Kan mø friste e med nook gøtt te kaffen? Bokmål: Kan vi friste deg med noe godt til kaffen? Nynorsk: Kan vi/me friste deg med noko godt til kaffen? English gloss: 'Can we tempt you with something good [to go] with [your] coffee?'

with, urban spaces and experiences. Yet there are also obvious contradictions in national discourses that have consistently extended social, economic, and political privilege to urban, cosmopolitan Norway, all the while claiming a decidedly romantic fondness and longing for traditional life in the countryside. In the present moment of recreational and heritage tourism growth for Valdres, local speakers and writers seem finally able to capitalize on their language and culture, both symbolically and economically, gaining social ground against less distinctive urban forms.

Rejecting the idea that rural people, livelihoods, and language are less worthy, Valdresmål users present traditional local spoken forms as desirably distinctive, deploying them in innovative ways and for new purposes, including in public, written domains heretofore reserved for standardized Bokmål and Nynorsk. As we see orthographically nonstandard representations of Valdresmål flourish in digital and commercial writing, the historically dominant ideological distinction between written and spoken language is challenged, and the ideological contradictions inherent in having two written norms are perhaps once again brought to the surface. While the dual written norm situation and 
variation among spoken regional dialects have long been accepted, here Valdresmål is refunctionalized, gaining legitimacy as a written code in public contexts, at least locally. Moreover, as written Valdresmål utterances are constructed in ways that appear to aim for the greatest possible degree of markedness, orthographic nonstandardness indexes not just local linguistic distinctiveness but also the social and linguistic distance between urban and rural places and speakers, underscoring the maintenance of ideological distance as desirable at a time when tourism and other mobilities bring more direct and sustained contact with non-local language and people.

Finally, in observing the rapid development of new orthographic conventions for written Valdresmål, including those that go a step or more beyond what might be necessary to represent phonetic divergence from standard Bokmål, Nynorsk, or Urban Eastern Norwegian forms, the legitimacy of standard spellings may be implicitly called into question, and their arbitrariness laid bare. And yet, perhaps ironically, the popular normalization of orthographic conventions for Valdresmål would seem to introduce a new yardstick against which local linguistic innovation and change might be measured in the future, fixing currently nonstandard spellings in the realm of the expected and narrowing what is perceived as truly local language.

Acknowledgements: Portions of this research were supported by grants from the Wenner-Gren Foundation and the American-Scandinavian Foundation.

\section{References}

Aars, Ivar. 1963. Substantiv i Nord-Aurdal: Oppland [Nouns in Nord-Aurdal, Oppland province]. Oslo: University of Oslo hovedfag thesis.

Androutsopoulos, Jannis. 2011. Language change and digital media: A review of conceptions and evidence. In Tore Kristiansen \& Nikolas Coupland (eds.), Standard language and language standards in a changing Europe, 145-160. Oslo: Novus.

Auer, Peter, Frans Hinskens \& Paul Kerswill (eds.). 2005. Dialect change: Convergence and divergence in European languages. Cambridge, UK: Cambridge University Press.

Bakhtin, Mikhail M. 1981. The dialogic imagination. Austin: University of Texas Press.

Beito, Olav T. 1959. Valdresmålet. In Knut Hermunstad (eds.), Valdres bygdebok, Vol. 2.

Fagernes: Valdres Historielag.

Bucholtz, Mary. 2007. Variation in transcription. Discourse Studies 9(6). 784-808.

Bucken-Knapp, Gregg. 2003. Elites, language, and the politics of identity: The Norwegian case in comparative perspective. Albany: State University of New York Press.

Crystal, David. 2000. Language death. Cambridge, UK: Cambridge University Press.

Crystal, David. 2006. Language and the internet. 2nd edn. Cambridge, UK: Cambridge

University Press. 
Duchêne, Alexandre \& Monica Heller (eds). 2012. Language in late capitalism: Pride and Profit. New York: Routledge.

Eisentstein, Jacob. 2015. Systematic patterning in phonologically-motivated orthographic variation. Journal of Sociolinguistics 19(2). 161-188.

Eriksen, Thomas Hylland. 1993. Being Norwegian in a shrinking world: Reflections on Norwegian identity. In Anne Cohen Kiel (eds.), Continuity and change: Aspects of contemporary Norway, 11-37. Oxford: Scandinavian University Press.

Fishman, Joshua A. 1991. Reversing language shift. Clevedon: Multilingual Matters.

Haugen, Einar. 1966. Language conflict and language planning: The case of modern Norwegian. Cambridge, MA: Harvard University Press.

Heller, Monica. 2011. Paths to Post-Nationalism: A Critical Ethnography of Language and Identity. New York: Oxford University Press.

Irvine, Judith T. 2001. "Style" as distinctiveness: The culture and ideology of linguistic differentiation. In Penelope Eckert \& John R. Rickford (eds.), Style and sociolinguistic variation, 21-43. Cambridge, UK: Cambridge University Press.

Irvine, Judith T. \& Susan Gal. 2000. Language ideology and linguistic differentiation. In Paul V. Kroskrity (eds.), Regimes of language: Ideologies, polities, and identities, 35-83. Santa Fe: SAR Press.

Jaffe, Alexandra. 1996. The second annual corsican spelling contest: Orthography and ideology. American Ethnologist 23(4). 816-835.

Jaffe, Alexandra. 1999. Ideologies in action: Language politics on Corsica. Berlin: Mouton de Gruyter.

Jaffe, Alexandra. 2000. Introduction: Non-standard orthography and non-standard speech. Journal of Sociolinguistics 4(4). 497-513.

Jaffe, Alexandra. 2008. Transcription in practice: Non-standard orthography. Journal of Applied Linguistics 3(2). 163-183.

Jahr, Ernst Håkon. 2014. Language planning as a sociolinguistic experiment: The case of modern Norwegian. Edinburgh: Edinburgh University Press.

Jahr, Ernst Håkon \& Karol Janicki. 1995. The function of the standard variety: A contrastive study of Norwegian and Polish. International Journal of the Sociology of Language 115. 25-45.

Jones, Taylor. 2015. Toward a description of African American vernacular english dialect regions using "Black Twitter.". American Speech 90(4). 403-440.

Jullumstrø, Fredrik Solbu. 2014. Flere Hytter enn Folk i Valdres. NRK Hedmark og Oppland. http://www.nrk.no/ho/1.11586533 accessed 6 March 2014.

Kvåle, Karen Marie. 1999. Eit målføre i uføre: Talemålsendring $i$ Valdres [A dialect in disarray: Dialect change in Valdres]. Oslo: University of Oslo hovedfag thesis.

Mæhlum, Brit. 2009. Standardtalemål? Naturligvis! En argumentasjon for eksistensen av et norsk standardtalemål [Standard spoken language? Naturally! An argument for the existence of a Norwegian spoken standard]. Norsk Lingvistisk Tidsskrift 27(1). 7-26.

Nesse, Agnete. 2015. Bruk av dialekt og standardtalemål i offentligheten i Norge etter 1800 [Use of dialect and standard speech in public in Norway after 1800]. In Helge Sandøy (eds.), Talemål etter 1800: Norsk i jamføring med andre nordiske språk [Spoken language after 1800: Norwegian in comparison to other Nordic languages], 89-111. Oslo: Novus.

Preston, Dennis R. 1982. 'Ritin' fowklower daun 'rong: Folklorists' failures in phonology. The Journal of American Folklore 95. 304-326.

Preston, Dennis R. 1985. The Li'l Abner Syndrome: Written representations of speech. American Speech 60(4). 328-336. 
Røyneland, Unn. 2009. Dialects in Norway: Catching up with the rest of Europe? International Journal of the Sociology of Language 196/197. 7-30.

Sandøy, Helge. 2009. Standardtalemål? Ja, men ...! [Standard spoken language? Yes, but...!]. Norsk Lingvistisk Tidsskrift 27(1). 27-47.

Schieffelin, Bambi \& Rachelle Charlier Doucet. 1992. The "real” Haitian Creole: Metalinguistics and orthographic choice. Pragmatics 2. 427-444.

Sebba, Mark. 2007. Spelling and society: The culture and politics of spelling around the world. Cambridge, UK: Cambridge University Press.

Strand, Thea R. 2012a. Dialect as style in Norwegian mass media. In Juan Manuel HernándezCampoy \& Juan Antonio Cutillas-Espinosa (eds.), Style-shifting in public: New perspectives on stylistic variation, 185-203. Amsterdam: John Benjamins.

Strand, Thea R. 2012b. Winning the dialect popularity contest: Mass-mediated language ideologies and local responses in rural Valdres, Norway. Journal of Linguistic Anthropology 22(1). 23-43.

Strand, Thea R. 2015. Pro-dialect practices and linguistic commodification in rural Valdres, Norway. In Eivind N. Torgersen, Stian Hårstad, Brit Mæhlum \& Unn Røyneland (eds.), Language variation - European perspectives V, 211-223. Amsterdam: John Benjamins.

Wangensteen, Bøye. 1971. Skilnader i ordtilfanget $i$ Vangsmålet hjå eldre og yngre [Differences in vocabulary in the Vang dialect among older and younger speakers]. Oslo: University of Oslo hovedfag thesis.

Ween, Gro \& Simone Abram. 2012. The norwegian trekking association: Trekking as constituting the nation. Landscape Research 37(2). 155-171.

Woolard, Kathryn A. 1985. Language variation and cultural hegemony: Toward an integration of sociolinguistic and social theory. American Ethnologist 12(4). 738-748.

Woolard, Kathryn A. \& Bambi B. Schieffelin. 1994. Language ideology. Annual Review of Anthropology 23. 55-82.

Wroblewski, Michael. 2012. Amazonian Kichwa proper: Ethnolinguistic domain in pan-Indian Ecuador. Journal of Linguistic Anthropology 22(1). 64-86. 